\title{
Preliminary Phitochemical Analysis of Guava Leaves (Psidium guajava L.) as Antidiarrheal in Calves
}

\author{
I Wayan Sudira ${ }^{1}$, I Made Merdana $^{1 *}$, Suci Nur Qurani² \\ Veterinary Pharmacology and Pharmacy Laboratory, Faculty of Veterinary Medicine, Udayana University ${ }^{1}$ \\ Profession Degree in Veterinary Medicine, Faculty of Veterinary Medicine, Udayana University ${ }^{2}$ \\ Jl. P.B. Sudirman, Denpasar, Bali, Indonesia \\ *Corresponding author: imade_merdana@unud.ac.id
}

\begin{abstract}
Guava plants (Psidium guajava L) are fruit plants originating from South America and can thrive in the territory of Indonesia. Now the biggest center for guava cultivation is spread in DKI Jakarta, West Java, Central Java, East Java, Yogyakarta, Bali, West Nusa Tenggara, Sumatra and Kalimantan. In addition to taking the fruit, guava leaves are also used as a traditional medicine for the treatment of diarrhea in human and animals. This study aims to identify active compounds in guava leaves. There are several secondary metabolites with pharmacological effects as anti diarrhea such as flavonoid, alkaloid, tannins and essential oils. The leaves sample used in this study were taken from farmers in the West Denpasar area, Bali. Extraction of guava leaf leaves was done using $96 \%$ ethanol, and phytochemical analysis was carried out to detect the presence of active compounds. The data obtained is presented and analyzed descriptively qualitatively. The results showed that the ethanol extract of guava leaves contained active compound included steroid, triterpenoid, phenolics, alkaloids, flavonoids, saponins and tannins. It can be concluded that guava leaf extract contains active compounds that are potential antidiarrheal.
\end{abstract}

Keywords: antidiarrheal, guava leaves extract, phytochemical

\section{INTRODUCTION}

Indonesia is a tropical country that has a large collection of plants with medicinal potential, which has been used as a traditional medicine for generations. The use of phytopharmaca tends to increase with the issue of back to nature and the financial crisis which results in weak purchasing ability [1]. This condition is supported by the understanding of people who consider traditional medicine to be safer without side effects and also easier to obtain without a prescription [2]. Traditional medicine is widely used by the middle to lower classes, especially in efforts to prevent, promote and rehabilitate. At present, one of the plants that is widely cultivated and has medicinal properties is a guava [3].

Guava plants were first grown in South America. The distribution of this plant has been found worldwide, especially tropical countries including Indonesia [4]. In Indonesia, the largest guava cultivation center covers the area of DKI Jakarta, West Java, Central Java, East Java, Yogyakarta, Bali, West Nusa Tenggara, Sumatra and Kalimantan. As it is known, these tropical plants are planted for fruit, but the leaves can be used for medicine [5]. Review article mentions this plant shows a variety of biological activities such as antidiarrheal, antimicrobial, antioxidant, hepatoprotective, anti-allergic, anti- spasmodic, anti-diabetic, anti-inflammatory and antitussive activity [6].

Guava fruit contains many nutrients, vitamins and antioxidants compound. It has been reported that there are $100 \mathrm{mg}$ ascorbic acid in $100 \mathrm{~g}$ of ripe guava fruit. Both active ingredients are reported to play a role in immunostimulants [7]. While the leaves are reported to contain flavonoids, alkaloid, triterpenoid, tannins and essential oils [8]. Flavonoids especially quercetin, alkaloids and tannins act as antidiarrhea [9]. Essential oils have the potential as antibacterial [10]. Other studies revealed guava leaf extracts can increase the number of platelets [11] and accelerate the healing of open wounds in mice [12-13]. Ascorbic acid, flavonoids and tannins are reported to have a potential to increase platelets in patients with dengue fever [14].

In this study phytochemicalscreening was carried out to determine the active compounds of guava leaves taken from the West Denpasar sub-district, Bali. This extract will be used for research as antidiareous candidates in Balinese calves. Calf diarrhea is a disease commonly reported in neonatal to young animals [15]. Some causes of diarrhea in calves include metabolic disorders, poor quality nutrition, infectious agents and non-infectious agents [16]. Infectious agents include enteropathogenic bacteria [17] viruses [15][18] and protozoa [19]. Diarrhea causes 
economic losses for farmers, in the form of medical expenses, care workers, disruption of growth and risk of death. The morbidty is very high reaching $62 \%$ with mortality case $39 \%$ [16].

Handling of calf diarrhea is generally based on clinical symptoms. The technology for controlling diarrhea in livestock has experienced development such as vaccines and synthetic drugs. But the treatment of diarrhea using herbal medicine such as guava leaves is potential to be developed, considering this plants also acts as an immunomodulator and the farmer can easily be cultivated around the enclosure garden.

\section{RESEARCH METHOD}

\section{Preparation of guava leafs extract}

Dried simplicia of fresh guava leaves was blended into powder. The powder weighed 1500 gram, was then processed by maceration method with $96 \%$ ethanol for a week at room temperature. The macerated are then filtered with a filter paper. The supernatant was evaporated in a rotary evaporator at temperature $40^{\circ} \mathrm{C}$. Ethanol extract of guava leaves can be stored until further examination. Phytochemical screening was carried out to identify the class of active compounds contained in the extract.

\section{Phytochemical analysis}

The phytochemical screening procedure was conducted according to Harborne (1987). This inclauded examination of steroids and terpenoids, phenolic, tannins, flavonoids, alkaloids, and saponin [20].

Steroids and terpenoids test; guava leaf extract was mixed with anhydrous acetic acid and sulfuric acid (Liebermann Burchad) each of 2 drops. The blue discoloration will indicate the presence of steroids and if the colour change to purple, will indicate the presence of terpenoids.

Phenol test; guava leaf extract was added by 2 drops of $\mathrm{FeCl} 3$ solution, blue to black color showed phenol content in the extract.

Tannin test; guava leaf extract was added by 2 drops of solution of $\mathrm{FeCl} 3$ and $\mathrm{H} 2 \mathrm{~N} 4$ into the test tube. The positive results of the tannin on the extract will show a yellowish color.

Flavonoids test (Wilstater Reagent); $1 \mathrm{ml}$ of guava leaf extract was added by 2 drops of concentrated $\mathrm{HCl}$ and added 0.2 milligram $\mathrm{Mg}$ powder, the positive reaction will show a yellow discoloration. Flavonoids test $(\mathrm{NaOH}$ Reagent); $1 \mathrm{ml}$ of guava leaf extract was added by added 2 drops of $10 \% \mathrm{NaOH}$ reagent, a positive reaction will show an orange or red color change.

Alkaloids test (Mayer reagent); $1 \mathrm{ml}$ of guava leaf extract was added by 2 drops of chloroform and 2 drops of meyer reagent, a positive reaction of the alkaloid showed the formation of white deposits.

Saponin test; guava leaf extract was added by 2-3 drops of distilled water hen shake the test tube slowly, the positive results of saponin content are indicated by the presence of foam in the test tube. Addition of $\mathrm{HCl}$ solution aims to stabilize the foam.

\section{Data analysis}

The data obtained is presented and analyzed by descriptively qualitatively.

\section{RESULT AND DISCUSSION}

The results of screening test of guava leaf extract showed that guava leaf contained secondary metabolites included steroids, terpenoids, flavonoids, alkaloids, tannins, phenols and saponins (Table I).

TABLE 1

PHIT OCHEMICAL SCREENING OF GUAVA LEAFS EXTRACT

\begin{tabular}{|c|c|c|c|c|}
\hline No & $\begin{array}{c}\text { Type } \\
\text { analysis }\end{array}$ & Reagent & $\begin{array}{l}\text { Discol- } \\
\text { ration }\end{array}$ & Test result \\
\hline 1 & $\begin{array}{l}\text { Steroid/ } \\
\text { Terpenoids }\end{array}$ & $\begin{array}{l}\text { Sample + } \\
\text { Anhydrous } \\
\text { acetic acid + } \\
\text { sulfuric acid } \\
\text { (Liebermann } \\
\text { Burchard) }\end{array}$ & $\begin{array}{c}\text { Blue } \\
\text { Purple }\end{array}$ & $\begin{array}{l}(+) \text { Steroid } \\
(+) \text { Terpenoid }\end{array}$ \\
\hline 2 & Fenolics & $\begin{array}{l}\text { Sample }+ \\
\mathrm{FeCl}_{3}\end{array}$ & Dark blue & (+) Fenolic \\
\hline 3 & Tannins & $\begin{array}{l}\text { Sample }+ \\
\mathrm{FeCl}_{3}+\mathrm{H}_{2} \mathrm{~N}_{4}\end{array}$ & Yellow & (+) Tannin \\
\hline 4 & Flavonoids & $\begin{array}{l}\text { Sample + } \\
\mathrm{Mg} / \mathrm{HCl}\end{array}$ & Yellow & (+) Flavonoid \\
\hline 5 & Flavonoids & $\begin{array}{l}\text { Sample }+ \\
\mathrm{NaOH} 10 \%\end{array}$ & Red & (+) Flavonoid \\
\hline 6 & Alkoloids & $\begin{array}{l}\text { Sample + } \\
\text { kloroform + } \\
\text { meyer }\end{array}$ & $\begin{array}{c}\text { White } \\
\text { sediment }\end{array}$ & (+) Alkaloid \\
\hline 7 & Saponins & $\begin{array}{l}\text { Sample + } \\
\text { aquades }+\mathrm{HCl}\end{array}$ & $\begin{array}{l}\text { Stable } \\
\text { foam }\end{array}$ & (+) Saponin \\
\hline
\end{tabular}

Steroids and terpenoids tests using the LiebermannBouchard method showed positive results, marked by changes in color to blue-green (steroids) and red-purple discoloration (terpenoids) This is due to the ability of terpenoid and steroid compounds to result colors by sulfuric acid in anhydride acetic acid solvents [21].

Examination of phenol compounds on guava leaf extract showed positive results. Phenolic compounds that react with $\mathrm{FeCl} 3$ cause discoloration to purple, blue and deep black. This is due to the reaction between $\mathrm{FeCl} 3$ and the $\mathrm{OH}$ aromatic group on phenol compounds [22].

Examination of tannin compounds by adding guava leaf extract with a solution of $\mathrm{FeCl} 3$ and $\mathrm{H} 2 \mathrm{~N} 4$ (hydrazine) showed a positive result marked discoloration to yellowish [10]. Tanin in celery leaves is reported as an antioxidant 
that can reduce total cholesterol and LDL cholesterol in hyperglycemic mice. The mechanism of tannin in reducing total cholesterol levels by inhibiting LDL oxidation [23]. Tanin has scavenger activity of hydrogen peroxide $(\mathrm{H} 2 \mathrm{O} 2)$, thereby reducing the formation of free radicals and lipid peroxidation [24].

Flavonoid test used two methods, namely Wilstater reagent and $10 \% \mathrm{NaOH}$ reagent. Both methods showed positive results of guava leaf extract containing flavonoids. Wilstater reagents were carried out by adding concentrated $\mathrm{Mg}$ and $\mathrm{HCl}$ to the sample. The addition of concentrated $\mathrm{HCl}$ was used to hydrolyze flavonoids into their aglycones by hydrolyzing O-glycosyl. Glycosyl will be replaced byH+ from acid because of its electrophilic nature. Reductions with concentrated $\mathrm{Mg}$ and $\mathrm{HCl}$ can produce complex compounds that are red or orange in flavonol, flavanone, flavanonol and xanton. Based on previous study phytochemical screening of alcoholic extract root bark of guava. Flavonoids have been reported to have free radical scavenger properties. Flavonoids existing in the extracts could play an important role and are phenolic compounds widely distributed in the plant kingdom and have several pharmacological properties such as spasmolytic and antidiarrhoeal activities Flavonoids are secondary metabolites that act as exogenous antioxidants [25][26].

Alkaloid test with Mayer reagent showed positive results marked white crystal sediment. In this reaction a bond is replaced where nitrogen which has a free electron pair on the alkaloid forms a covalent coordinate bond with a $\mathrm{K}+$ ion from potassium tetraiodobismutat to produce a precipitate of potassium-alkaloid complex. Other studies reveal alkaloids as powerful antioxidants that are good for protecting cells from damage caused by free radicals and toxicity [22].

The saponin test showed a positive result because of the foam formed after the shaking of the sample and distilled water, with the addition of $\mathrm{HCl}$ foam solution stabilized [20]. Saponins have glycosyl as a polar group and steroids as nonpolar groups, which are surface active and will form micelles when shaken with water [27]. The study report that saponins have antioxidant and antibacterial effects [22][25][28].

Multiple pathogens are known to contribute to the development of calf diarrhea. Other factors that influence the severity of the disease include the environment and management practices. This multifactorial nature makes calf diarrhea difficult to control [15]. The morbidity and mortality are very high in newborn cows and young animals. This causes high economic losses due to calf deaths, high medical costs and stunted growth [29]. Noninfectious calf diarrhea is triggered by a bad environment, cold temperatures, a changing feed program, overcrowding facility or other mechanical causes [16]. Infectious diarrhea may be caused by bacterial, viral and protozoan infections [15-16].

The results of this study, analysis of revealed that guava leaf extract contained phytochemicals that are known to have pharmacological activity. Flavonoids are hydroxylated polyphenolic compounds that have a response to microbial infections [15]. Tannin is a polyphenol compound with anti-bacterial activity, which is capable of binding a lot of proline protein [30]. Both of these activities are able to form complex bonds with intracellular and extracellular proteins and lyse bacterial cell walls. Other reports mention terpenoids, saponins and essential oils also effectively inhibit bacteria [10][31]. Secondary metabolites in guava leaf extract showed immunostimulatory [24-25][28] activity such as; increasing platelet [11][14] in protecting grouper liver from viral nervous necrosis (VNN) infection [18].

The in vitro antimicrobial activity of guava leaf extract is indicated by the ability to inhibit gram-positive bacteria (Bacillus aureus and Staphylococcus aureus) [12], Escheresia coli [10], Pseudomonas aeruginosa, E. coli, S. aureus, Streptococcus pneumoniae and Klebsiella pneumonia [31], Aspergillus niger and Candida albicans [30], and viral nervous necrosis [18]. All of these abilities of guava leafs extract have the potential to be developed as anti-diarrhea in calves.

\section{CONCLUSION}

The phytochemical analysis the ethanolextract of guava leaves contained active compound inclauding steroid/triterpenoid, phenolics, alkaloids, flavonoids, saponins and tannins. Thus the guava leaves extract has the potential to treatment of diarrhea in calves.

\section{ACKNOWLEDGMENT}

The authors thanks to The Rector of Udayana University, The Dean of Faculty Veterinary Medicine and The Head of Research and Community Service for research grant (PNBP PUPS 2018).

\section{REFERENCES}

[1] Wibisono, W.G. 2011. Tanaman Obat Keluarga Berkhasiat. Vivo publisher, Jawa Tengah

[2] Mustofa, F.I., N. Rahmawati. 2018. Studi etnofarmakologi tumbuhan obat yang digunakan oleh penyehat tradisional untuk mengatasi diare di sulawesi selatan. Jurnal Tumbuhan Obat Indonesia, 11(2): 17-32.

[3] Nugraha, A.S., P.A. Keller. 2011. Revealing indigenousIndonesian traditional medicine: anti-infective agents. Natural Product Communications, 6 (12), 1953-1966.

[4] Barbalho, S.M., M.V. Flávia M. Farinazzi, D.A. Ricardo, A. Cláudia, S. Brunnati, A. Maria, B. Ottobon, C. Nicolau. 2012. Metabolic Profile of Offspring from Diabetic Wistar RatsTreated with Mentha piperita (Peppermint) Evid Based Complement. Alternat Med.pp 1-6. 
[5] Trubus. 2013. 100 Plus Herbal Indonesia. Vol.11. Trubus, Depok. Issn 0216-7638.

[6] Sanda, K.A., H.A. Grema, Y.A. Geidam, Y.M. Bukar-Kolo. 2011. Pharmacological Aspects of Psidium guajava: An Update. International Journal of Pharmacology, 7: 316-324.

[7] Puspaningtyas, A.R. 2012. Evaluation of the effect of red guava (Psidium guajava) fruit extract on tyrosinase activity by pectrophotometry, International Current PhamaceuticalJoumal, 1(5): 92-97.

[8] Agustina, E., F. Andiarna, N. Lusiana, R. Purnamasari, M.I. Hadi. 2018. Identifikasi senyawa aktif dari ekstrak daun jambu air (Syzygium aqueum) dengan perbandingan beberapa pelarut pada metode maserasi. Biotropic, 2(2): 108-118.

[9] Fratiwi, Y. 2015. The potential of guava leaf (Psidium guajavaL.) for diarrhea. Journal Majority, 4(1): 113-118.

[10] Maysarah, H., R. Apriani, Misrahanum. 2016. Antibacterialactivity test $f$ ethanol extract of white and red flesh fromguavaleaf(Psidium guajava. L) againts Staphylococcus aureus and Escherichia coli. Jurnal Natural, 16(1): 51-56.

[11] Arifin, H., Agustina, Z. Rizal. 2013. Pengaruh pemberianjusjambu biji merah (Psidium guajava L.) terhadap jumlah sel eritrosit, hemoglobin, trombosit dan hematokrit pada mencit putih.Jumal Sains dan Teknologi Farmasi, 18(1): 43-48.

[12] Biswas, B., K. Rogers, F. McLaughlin, D. Daniels, A. Yadav.2013. Antimicrobial activities of leaf extracts of guava (Psidium guajava $L$.) on two gram-negative and gram-positive bacteria. Int $J$ of Microbiology, Vol 2013 (746165): 1-7.

[13] Desiyana, L.S., M.A. Husni, S. Zhafira. 2016. Uji efektivitas sediaan gel fraksi etil aset at daun jambu biji (Psidium guajavaLinn) terhadap penyembuhan luka terbuka pada mencit (Musmusculus). Jurnal Natural, 16(2): 23-32.

[14] Prasetio, J.N. 2015. Potential red guava juice in patients with dengue hemorrhagic fever. Journal Majority, 4(2): 25-29.

[15] Cho, Y., K.J. Yoon. 2014. An overview of calf diarrhea-infectious etiology, diagnosis, and intervention. J. Vet. Sci. 15(1), 1-17.

[16] Rahayu, I.D. 2014. Identifikasi penyakit pada pedet perah pra-sapih di peternakan rakyat dan perusahaan peternakan. JumalGamma, 9(2): 40-49.

[17] Muktar, Y., G. Mamo, B. Tesfaye, D. Belina. 2015. A review on major bacterial causes of calf diarrhea anf its diagnostic method. $J$. Vet. Med and Animal Health, 7(5): 173-185.

[18] Amelia, N., S.B. Prayitno. 2012. Pengaruh ekstrak daun jambubiji (Psidium guajava) untuk menginaktifkan Viral Nervous Necrosis (vnn) pada ikan kerapu bebek (Epinephelus fuscoguttatus). J Of Aquaculture Management \& Tech, 1(1): 264-278.

[19] Wisesa, I.B.G.R., F.M. Siswanto, T.A. Putra, I.B.M. Oka, N.A. Suratma. 2015. Prevalence of Balantidium $s p$ in bali cattle at different areas of bali. Int J of Agr, For. and Plant., Vol. 1 (Sept.): 49-53.

[20] Harborne, J.B. 1987. Metode Fitokimia Penuntun Cara Modern Menganalisis Tumbuhan. Penerbit ITB. Bandung.

[21] Marliana, S.D. and Saleh, C. 2011. Uji Fitokimia dan Aktivitas Antibakteri Ekstrak Kasar Etanol, Fraksi n-Heksana,Etilasetat,dan Metanol dari Buah Labu Air (Lagenari Siceraria). J. Kimia Mulawarman 8(2): 39-63.

[22] Haryati, N.A. and Erwin, C.S. 2015. Uji Toksisitas dan Aktivitas Antibakteri Ekstrak Daun Merah (Syzygium mytifolium Walp) terhadap Bakteri Staphylococus aureus dan Escherichia coli. $J$. Kimia Mulawarman. 13(1): 35-39.

[23] Umarudin, Susanti, R and Yuniastuti, A. 2012. Efektivitasekstrak tannin seledri terhadap profil hiperkolesterolemi lipid tikusputih. Unnes Journal of Life Science 1(2): 78-85.

[24] Aripasha A., D. Andriana,Y. Purnomo. 2015. Efek dekok daun pulutan (Urena lobata) terhadap kadar SOD (Superoxyde dismutase) dan MDA (Malondialdehyde) serum tikus model diabetes mellit us tipe II. Jurnal Kedokteran Komunitas 3(1):304311 .

[25] Hu. Y., Xu, J. and Hu, Q. 20013. Evaluation of antioxidant potential of Aloe vera (Aloe barbadensis Miller) extracts. J. Agricultureand Food Chemistry 51: 7788-7791.

[26] Ramya, Kuber., M. Rajya, Lakshmi., E. Deepika., P. Yamini.2013. Phytochemical screening invitro anti-bacterial and antioxidant activity of the Psidium guajava root bark. Int. J. Curr. Microbiol. App. Sci, 2(10): 238-248.

[27] Sangi, M., Runt uwene, M.R.J., Simbala, H.E., and Makang V.M.A. 2008. Analisis Fitokimia Tumbuhan Obat di Kabupaten Minahasa Utara. Chem. Prog. 1(1): 47-53.

[28] Akinpelu, B.A., O.A. Igbeneghu, A.I. Awotunde, E.O. Iwalewa, O.O. Oyedapo. 2014. Antioxidant and antibacretial activities of saponin fractions of Erythropheleum suaveolens (Guill andPerri) stem bark extract. Science Research Essays 18(9): 826-833.

[29] Malik, S., A.K. Verma, A. Kumar, M.K. Gupta, S.D. Sharma. 2012. Incidence of Calf Diarrhea In Cattle and Bufallow Calves in Uttar Pradesh, India. Asian Jornal of Animal and VeterinaryAdvadences. 7 (10): 1049-1054.

[30] Mailoa, M.N., M. Mahendradatta, A. Laga, N. Djide. 2016. Antimicrobial activities of tannins extract from guava leaves (Psidium guajava L) on pathogens microbial. Int. J.ofSci \& Tech. Res, 3(1): 236-241.

[31] Kenneth, E., T. Paul, N. Istifanus, U. Uba, A. Rejoice, O. Victor,S Mohammed. 2017. Phytochemical analysis and antibacterial activity of Psidium guajava L. leaf extracts. GSC Bio andPham Sci, 01(02): 013-019. 